graphical sketches of the four men who probably had most influence on Darwin-Erasmus Darwin, Lyell, Hooker and Malthus. The essay on Malthus by Prof. H. J. Habakkuk is of special interest and shows how, with his writings on population, Malthus provided the clue to the origin of the species both for Darwin and for A. R. Wallace. This special copy of Notes and Records was designed to pay tribute to Darwin, and in itself is a tribute both to him and the Society which sponsored it.

\section{Education as a Career}

THe Ministry of Education has published a pam. phlet intended to give university students a picture of the opportunities which exist for men and women to follow a career in education " $A$ Career in Education for University Graduates". Revised edition. Pp. 15. London: Ministry of Education, 1959). It describes the training and types of work open to university graduates who become schoolmasters and schoolmistresses, with particular reference to work in grantaided schools. It also refers to the financial aid available towards the cost of training. The appendixes which follow give up-to-date facts about teachers' salary scales in schools and about teachers' pensions. They also include some information about opportunities for teaching in establishments of further education and training colleges, and for work in local educational administration and H.M. Inspectorate. There are also opportunities for educational work in a variety of other spheres, both in Great Britain and abroad, and some of these are described.

\section{Handicapped Children}

THE thirteenth in a series of special subject booklists prepared for the Library Association deals with handicapped children in Britain ("Handicapped Children in Britain-Their Problems and Education". Books and Articles published in Great Britain from the 1944 Education Act to 1958. Compiled by Mrs. W. A. Axford. Pp. 53. London : Library Association, 1959. 4s.). The compiler, Mrs. W. A. Axford, of the University of Birmingham Institute of Education, deserves the warmest praise for a painstaking task well done; the list includes details of books and articles published in Great Britain from the 1944 Education Act to 1958. The bibliography covers all types of physical and mental handicap, but not psychological or social handicaps. Articles of a purely medical nature are excluded unless they are of general interest. For easy reference the items are arranged in alphabetical sequence of subject headings.

\section{Film Strips for Schools}

DespITE the exciting potentialities of moving films and television as means of evoking interests in schoolchildren, the teaching profession as a whole regards the still picture as an even greater aid to teaching. The moving picture awakens interest and captures attention; teachers use still pictures to ensure that factual knowledge is retained. For this reason, they will once again be grateful to the enterprising firm of Educational Productions, Ltd., for adding four more attractive and inexpensive coloured film-strips to its wide range. One, showing a variety of common garden insects, has been prepared by the well-known photographer, George Hyde, and would be of interest to horticultural clubs as well as in school biology classes. "Resident British Birds" has been prepared in collaboration with the Royal Society for the Protection of Birds; the photographs are by Eric
Hosking and the script by Philip Brown. "Grasses" would be of particular use in sixth form and university botany classes, while "Seed Germination" should find a warm welcome in secondary modern, secondary grammar schools and others where biology is taught to the General Certificate of Education, 'Ordinary' level. (Educational Productions, Ltd. Filmstrip No. 5260 : Insects in the Garden. 28 frames. 16s. 6d. Filmstrip CX 6290 : Seed Germination. 23 frames. 27s. 6d. Filmstrip CX 6332 : Grasses. 27 frames. 27s. 6d. Filmstrip CX 6208 : Resident British Birds. 33 frames. 27s. 6d. East Ardsley, Wakefield : Educational Productions, Ltd., 1959.)

\section{Evolution of the Human Brain}

The James Arthur Lecture on the Evolution of the Human Brain, given by Prof. D. P. C. Lloyd, entitled "The Discrete and the Diffuse in Nervous Action", has now been issued (pp. ii +28 . New York: Amer. Mus. Nat. Hist., 1959). His central theme is Cajal's concept of "les réflexes unilatéraux circonscrits" and "les réflexes unilatéraux diffus". Much of Prof. Lloyd's work has been concerned with the functional implications of the anatomical distinction made by Cajal ; and in this lecture he elaborates the idea that the circumscribed monosynaptic reflex is an accurate, rapid and discrete functional arrangement of advanced evolutionary status. On the other hand, the diffuse reflexes involving interneurones constitute an organized, although more plastic, system for synergic mass actions. The latter are to be distinguished from the primitive mass action systems of many invertebrates by the 'local sign' they exhibit in performance. There is little in this theme that is controversial, and much that can now be considered as consolidated in physiological thought: but Prof. Lloyd, as the author of a substantial part of the experimental evidence, develops the theme with great clarity and point.

\section{Fodder Beet, Mangels and Swedes}

REvised leaflets describing varieties of fodder beet and mangel and of swedes have recently been issued by the National Institute of Agricultural Botany at Cambridge. In each of these crops the Institute has tested very large numbers of varieties, and these leaflets give details of the important root characters, the size of top and percentage bolters of the varieties which have proved most successful in the trials. These leaflets give the farmer the information he needs to make an intelligent choice from the bewildering range available. Copies can be obtained by sending a stamped addressed envelope, saying which leaflet is required, to the Secretary, National Institute of Agricultural Botany, Huntingdon Road, Cambridge.

\section{Announcements}

THE honorary officers and members of Council of the Association of Consulting Scientists for 1959-60 are: Chairman: Dr. J. G. Davis; Hon. Treasurer : Dr. G. W. Ferguson; Hon. Secretary: Mr. W. H. Stevens, Park House, / Hawthorne Road, Bromley, Kent ; Members : Dr. M. Barent, Dr. H. H. Chambers, Dr. J. Grant, Dr. J. H. Oliver, Mr. O. W. Roskill and Mr. F. G. Sarel Whitfield.

Erratum. In the communication entitled "A New Crystalline Salt of Oxytocin" in Nature of September 26 , p. 981, par. 3, line 4, for "33 m $\mu$ " read " $353 \mathrm{~m} \mu$ ". 